\title{
Nytt faderskap i \\ skärningspunkten \\ mellan produktion och \\ reproduktion?
}

\section{ULF MELLSTRÖM}

I denna artikel diskuteras hur nya former av maskuliniteter skapas mellan en stark jämställdhetsdiskurs och arbetslivets krav. Det avspeglas i det moderna faderskapets

praktik och relationen arbete/familj där produktionens krav överordnas reproduktionens. Artikeln argumenterar för att familje- och arbetslivsforskning i högre grad behöver uppmärksamma mäns respektive kvinnors rörelse mellan familj och produktion och hur genusidentitet förhandlas mellan dessa olika sfärer.

\section{Inledning}

Den här artikeln handlar om hur arbetsmarknad och yrkesidentitet sätter villkor för faderskapets utformande för män inom s.k. högteknologiska yrken med höga prestationskrav. Med utgångspunkt i ett antropologiskt arbete utfört i början av 1990-talet

Ulf Mellström är professor vid Luleå tekniska universitet
(Mellström 1995) samt kompletterande källor kommer jag att diskutera hur en ny form av manlig genusordning artikuleras $i$ ljuset av en stark svensk jämställdhetsdiskurs och en flexibel arbetsmarknad med höga prestationskrav på individen.

Med utgångspunkt i egen empiri, forskning kring faderskap och manlighet (Åström 1990, Berg \& Johansson 1999, Hagström 1999, Johansson 2001, Gavanas 2001, Plantin 2001, Klinth 2002) och 
ny forskning kring manliga arbetstagare (Nordberg 2005, Fogelberg-Eriksson 2005) och manlig ohälsa (Backman 2005) vill jag visa att många unga män och fäder inom så kallade karriäryrken slits mellan hem och arbete och att detta är del av en ny form av manlig genusordning. Dessa dubbla lojaliteter är en konstituerande del av deras vardagsverklighet och deras vardagsliv upptas ofta av förhandlingar mellan dessa olika livssfärer som hem och arbete utgör. Jag utgår med andra ord från att dessa olika livssfärers logik och rationalitet till stor del är motstridiga och att det sker en kontinuerlig förhandling mellan dessa rationaliteter (Asplund 1984). Annorlunda uttryckt är det en förhandling mellan produktionens och reproduktionens olika former av rationalitet. Arbetsdelningen inom familjen respektive arbetsdelningen på arbetsmarknaden är en genusarbetsdelning som påverkar både män och kvinnor (Duvander 2000, Oláh 2001, Björnberg \& Kollind 2003, Bergkvist \& Florin 2004).

Jag väljer att fokusera på män och fäder inom ett yrkesområde och en industriell sektor (informations- och kommunikationsteknologi, IKT) där skärningspunkten och förhandlingar mellan arbetsliv och familjetillvaro kan tydliggöras och där arbetets villkor formuleras i termer av höga prestationskrav. Det är en industri som till övervägande del är en manligt dominerad industri där "turbokapitalistiska" värderingar är rådande och där höga prestationskrav, långa arbetstider i flexibla organisationsformer, hängivenhet inför projekt och teknisk briljans ofta är honnörsord (Mellström 1995, Cooper 2000, Gunnarsson 2003). Det är också i dessa termer som manlighet ofta definieras och att klara dessa utmaningar blir i sig ett prov på manlig uthållighet och styrka. Den symboliskt starka kopplingen mellan teknologi och maskulinitet (Mellström 1995, 1999, 2002, 2003, 2004) gör vidare att IKT-sektorn är en intressant arena att studera utifrån hur den nu sätts under tryck av starka jämställdhetsdiskurser.

Cooper (2000 s. 385 ff) menar att nya former av maskulinitet inom den s.k. kunskapsindustrin skapas i relationen mellan självdisciplin, arbetsmoral, arbetstid, lojalitet och kontroll av arbetstagarna. Hon menar vidare att på en flexibel arbetsmarknad där arbetstagarens kunskapskapital är liktydigt med hans/hennes karriärmöjligheter blir kontrollen och övervakningen av arbetet alltmer individualiserad. Till skillnad från tidigare studier av s.k. normativ kontroll (Etzioni 1961, Kunda 1992) och identitetsbaserade former av självdisciplin $i$ arbetslivet så visar Cooper i hennes studier av »kunskapsarbetare» i Silicon Valley, USA, att det $\mathrm{i}$ hög grad bygger på olika former av genusordningar. Det är en arbetsprocess som bygger på en prestations- och tävlingsorienterad form av maskulinitet och vilket formar dessa mäns erfarenheter av faderskap och maskulinitet. Den tidigare forskningen kring internaliserade former av självkontroll i arbetslivet har mer eller mindre varit genusblinda. ${ }^{1}$ Coopers arbete visar på nya möjligheter att spegla mäns erfarenheter i relation till arbete och familj.

1 För en kritik av den här genusblindheten se exempelvis Alvesson \& Due-Billing 1997, Alvesson 1998 samt även för ett perspektiv som utvecklar genussensibel organisationsteoretisk plattform. 
Den hypotes som läggs fram i artikeln är att den formen av normativ kontroll som i hög grad praktiseras inom IKT-sektorn är en genusbaserad form av kontroll där en ny form av manlig genusordning går hand $\mathrm{i}$ hand med nya effektivitets- och lönsamhetskrav inom kunskapsindustrin. Jag bygger här vidare på och kombinerar insikter från de tre olika forskningstraditioner som i korthet redovisats ovan och som utvecklas successivt i artikeln. I kombinationen mellan genus- och maskulinitetsforskning, familjeoch arbetslivsforskning och forskning kring olika former av normativ kontroll öppnas möjligheter till nya analytiska ingångar. Kombinationen av dessa forskningstraditioner kan även appliceras inom andra yrkesområden och i samspelet mellan arbete och familj, men jag begränsar mig här till IKTsektorn. De teoretiska implikationerna för familje- och arbetslivsforskning, maskulinitetsforskning samt mellan genusforskning i stort är att analyser av genusordning bör försöka överbrygga uppdelningen hem och arbete för att kunna fånga vardagslivets meningsskapande processer.

\section{Metod och material}

Det empiriska materialet till den här artikeln härrör från ett niomånaders antropologiskt fältarbete i kombination med användning av livshistorier på ett mindre s.k. avknoppningsföretag (Mellström 1995). Med antropologiskt fältarbete menas här att dagligen befinna sig på plats och observera, samtala med och intervjua undersökningens informanter. Företaget "Microchips" ligger $i$ en forsknings- och teknikpark med nära koppling till en av Sveriges fem tekniska högskolor. "Microchips" affärsidé är att bistå den nordiska marknaden med kundanpassade integrerade kretsar. Företaget är ett förhållandevis litet företag inom den svenska halvledarindustrin. Småskalighet, stark teknikorientering, forskningsnärhet, pressade "deadlines", oregelbundna "fria" arbetstider och en informell arbetsorganisation är några av de viktigaste inslagen $\mathrm{i}$ arbetet på „Microchips«. Företaget hade när undersökningen genomfördes 23 anställda varav 15 är civilingenjörer (13 män och två kvinnor). ${ }^{2}$

Jag har genomfört livshistorieintervjuer med tio av civilingenjörerna varav åtta män och två kvinnor. Jag har även genomfört tio intervjuer med civilingenjörer vid Volvo Personvagnar i Göteborg (nio män och en kvinna). Intervjuerna med Volvoingenjörerna skedde i samband med insamling av data kring den svenska civilingenjörskåren (Mellström 1995, 2003, 2004). I förekommande fall används dessa intervjuer för att komplettera materialet från "Microchips". I dessa intervjuer som genomfördes i omgångar och var relativt omfattande kom vi att beröra arbete, uppväxt, familj, skola, utbildning, fritid med mera.

Den antropologiska metodens fördelar med deltagande observation och långa perioder av närvaro, detaljkunskap om lokala förhållanden och informantnära kunskap är också dess nackdelar. Detaljbeskrivningar av rutiner, informella strukturer och vardagsliv rimmar illa med generaliserande anspråk. Av nödvändighet tvingas antropo-

2 På grund av att „Microchips« är ett litet företag anonymiseras namnet på företaget. 
logen förlita sig på vad Brewer (1994 s. 236237) kallat den "etnografiska fantasin" (the ethnographic imagination). Den innefattar tre dimensioner av vilken den första är att antropologen förlitar sig på att småskaliga beskrivningar och analyser talar om större samhälleliga skeenden. Den andra är övertygelsen om att fragment från vardaglig social interaktion såsom inspelningar, observationer och fältanteckningar kan på ett tillförlitligt sätt spegla sociala världar. Den tredje dimensionen är övertygelsen om att människor skapar mening i sin vardag genom att berätta och redogöra för densamma. Om vi som socialvetenskapliga forskare skall kunna förstå den samhälleliga vardagens komplexitet bör vi härvidlag också analysera och lyfta fram dessa berättelser och redogörelser. Frågor kring validitet och vetenskaplig auktoritet vilar således på en rad olika förutsättningar när det gäller kunskapens produktion och presentation. Kunskapens natur blir av nödvändighet av en hypotesgenererande karaktär och så är det också i denna artikel. Empirin som presenteras i artikeln har som mål att på ett induktivt vis presentera rimliga tolkningar snarare än hypotessäkrande bevis.

\section{Arbete, faderskap och nya maskulinitetsordningar}

I litteraturen kring kvinnor och arbetsmarknad (Stark 1997, Björnberg \& Kollind 2003) har kvinnors strävan ut i offentligheten varit i fokus. Det emancipatoriska målet har definierats i termer av att bryta den könsmässiga segregeringen mellan hem och arbete. I den strävan är »kvinnligheten« his- toriskt på väg från hem till offentlighet. Det emancipatoriska målet med "manligheten" har varit det omvända, dvs. att få män att ta större ansvar för arbetsdelningen $\mathrm{i}$ hemmet (Klinth 2002). Att få män att träda in i hemmet kan ses som en gradvis historisk förskjutning där vi gått från sekelskiftets distanserade borgerlige fader till dagens »i-princip-jämställd-pappa" via 1950-talets "söndagspappa" och 1970-talets "mjukismanlighet" (Jalmert 1984, Åström 1990, Plantin 2001). Den normativa maskuliniteten med avseende på dagens moderna faderskap och så den kommer till uttryck i rådgivningslitteratur, riksdagsbeslut om pappamånad, i Socialstyrelsens föreskrifter med mera, är en man som ställer upp för sin familj och som är positiv till jämställdhet (Hagström 1999, Klinth 2002, Nordberg 2005).

Kvinnors och mäns livsvärldar har i ett historiskt ljus närmat sig varandra men åtskilliga strukturella respektive attitydmässiga hinder återstår innan vi kan tala om »dubbel emancipation«. Det visar inte minst den tillgängliga statistiken över fäder och fäders insatser inom hushållsarbetet. Endast var tionde svensk familj med småbarn eller barn i skolåldern är jämställda i bemärkelsen att de delar på hushållets uppgifter lika ofta (SOU 1998:003). Orsakerna härtill finner vi i argument kring ekonomisk rationalitet, maktfördelningen mellan könen samt könsstereotypa förväntningar på vad som är manligt respektive kvinnligt. Inte minst förklaringar kring ekonomisk rationalitet tenderar att användas av både män och kvinnor när de skall förklara ansvarsfördelningen $\mathrm{i}$ deras respektive familjer och de motiv som ligger till grund 
för en icke jämställd arbetsdelning. Mäns starkare förankring på arbetsmarknaden och generellt högre lön blir i praktiken ofta en avgörande faktor i vardagliga beslut trots att en stor del av dagens fäder uttryckligen menar att både arbetslivet och familjelivet utgör lika viktiga livsarenor.

Arbetslivetskrav framstår med andra ord som centrala för faderskapets utformande och manligheters utformande i stort. Ett centralt tema i litteraturen kring maskuliniteter och arbetsmarknad är vad Michael Kimmel (1994) benämnt som marknadens maskulinitet. Det är en form av maskulinitet som är förankrad i produktionen och bygger på ett aktivt deltagande $\mathrm{i}$ arbetslivet och stora investeringar i karriär och utbildning. Den bygger på homosocial konkurrens och kamratskap mellan män och utesluter inte sällan kvinnor (Holgersson 2003). En tydlig arbetsdelning mellan manligt och kvinnligt samt en uppdelning mellan arbete och familj ingår i den karriärorienterade livsformen. I den här traditionella patriarkala formen för arbetslivets och hemmets organisering har även mer moderna och nutida karriärorienterade maskuliniteter sitt historiska ursprung. Inom det privata näringslivet är den här klassiska maskulinitetsformen fortfarande den dominerande (Mellström 1995, Cooper 2000).

Färska doktorsavhandlingar inom maskulinitetsforskningen visar dock på en gradvis framväxt av nya maskulinitetsordningar (Nordberg 2005, Backman 2005, FogelbergEriksson 2005) där en stark samtida jämställdhetsdiskurs kommer till uttryck på olika sätt men framförallt ställer nya krav på faderskapets utformande och marknadens maskulinitet. Relationen mellan hem och arbete kommer alltmer i fokus för unga män och fäders identitetsarbete. Hemmet som arena blir allt viktigare att förhålla sig till. Den nu mer än fyrtio år gamla svenska jämställdhetspolitiska idén om »dubbel emancipation" (Klinth 2002) verkar nu ha fått en stark symbolisk och vardagspolitisk betydelse. Trots att marknadens maskulinitet fortfarande kan ses som den dominerande formen inom det privata näringslivet så ser vi en ökad grad jämställdhetspolitisk orientering på flera olika plan. I populärkulturen ser vi en allt bredare manlig känslorepertoar och variation av olika sätt att uttrycka manlighet. Backman (2005) visar hur mannen och det manliga objektifieras, sexualiseras och erotiseras i samtida reklam och medier som en del av en allt starkare konsumtionskultur men samtidigt tillåts gå bortanför klassiska bilder av mannen som stark och osårbar. En ökande problematisering av det privata och personliga har lett till en ökande grad av emotionalisering och intimisering av mannen och det manliga $i$ svensk populärkultur. En parallell process av en förändrad genusordning visar också Nordberg (2005) på i en avhandling om manliga arbetstagare i kvinnodominerade yrken. Nordberg (2005 s.75) menar att reell förändring har skett och att: „den svenska jämställdhetspolitiken och lagarna ändå rubbat könsmaktsordningen«. Detta skriver hon som motvikt till flera amerikanska maskulinitetsforskare (Hondagneu-Sotelo \& Messner 1994, Pfeil 1995, Adkins 2002) som uttrycker att en ny manlig sensitivitet inte talar om nya mer jämställda genusrelationer utan snarare en normomvandling som legitimerar, och understödjer mäns privilegier. Härvidlag indikerar Nordbergs forsk- 
ning en mer radikal förändring av manliga prioriteringar och maskulinitetsordningar i Sverige i jämförelse med exempelvis Förenta Staterna. Det senare är i hög grad en empirisk fråga att besvara och forskningen är ännu knappast mer än gryende. De resultat som presenteras i denna artikel ligger dock i linje med denna inriktning.

\section{Att vara med i laget}

Det är i ljuset av denna historiska förändringsprocess på två olika arenor som många av de män jag intervjuat känner att de "sitter i kläm». De upplever att de både vill vara lojala medspelare på arbetet och vara lojala med sina familjer. De vill ställa upp för företaget och vara en nyttig lagspelare samtidigt som de vill vara inkännande och ödmjuka pappor som deltar aktivt i barnens uppfostran.

Att vara en lagspelare som inte faller utanför ramen är återkommande metaforer när ingenjörerna beskriver hur de arbetar i projekten på »Microchips». I en arbetsorganisation där teknisk briljans, innovationer, kreativitet, hängivenhet inför uppgiften är honnörsord är det få som talar högt om ledningens orealistiska "deadlines». Samtidigt formuleras denna tidspress med utgångspunkt i lagspelsmetaforer och lagarbete. Tidsplaneringen för varje projekt var mycket snålt tilltaget. Ramarna var satta utifrån att vanliga arbetsuppgifter som tester, designlösningar och laserbränningar i renrummet fungerade vid den första körningen. Jag var aldrig med om att det skedde. Även om det från ingenjörernas sida ständigt klagades på ledningens orealistiska tidsplanering så var det samtidigt en sport att klara av de ibland horribelt långa arbetsdagarna. Karaktär, vilja och beslutsamhet var omdömen som cirkulerade kring de ingenjörer som klarade av att arbeta långt efter normal kontorstid. Att klara av att leverera färdiga kretsar på utlovad leveranstid var naturligtvis också en nödvändighet för företagets trovärdighet och rykte på marknaden.

Denna nödvändighet tolkades i termer av karaktärsfasthet och pur beslutsamhet. Ingenjörerna som ofta presenterades inför på förhand omöjliga tidsramar var tvungna att uppbringa en stark tävlingsinstinkt för att sätta sig över de hinder som uppenbarligen stod framför dem. Att klara projektens tidsramar tolkades generellt i termer av inre styrka och tävlingsmentalitet. Att vara en stark medspelare som man kan lita på var därför en mycket talande metafor för hur arbetets villkor omtalades på företaget. En speciell form av "maskulin mystik» kom också att omge de grabbar som använde nätter och helger för att klara av leveranstider till kund. Följaktligen var det ungkarlarna på företaget som mestadels stod för dessa långa arbetspass. Deras berättelser kring när den sedvanliga Coca-colan började blandas med rödvin framåt klockan 19-20 på fredagskvällen kombinerat med ett midnattligt besök på en av stadens studentpubar tillhörde exempelvis "folkloren" på företaget. Åtskilliga skämt, berättelser och anekdoter hämtade sin näring ur dessa mytomspunna nätter och helger på företaget.

Arbetstiderna omtalades i tre kategorier som speglade arbetsrytmen; kontorstid, ungkarlstid och extra ungkarlstid. Kontorstid är mellan klockan 8 och 17 alternativt 
mellan klockan 9 och 18. Ungkarlstid är kvällar och tidiga morgnar. Extra ungkarlstid är nätter och helger. Under min tid på företaget var det endast ett projekt av sammanlagt elva som inte gjorde bruk av extra ungkarlstid. Det senare var helt enkelt en resurs som ledningen kalkylerade med för att få ihop budgeten. Företagets VD medgav att det var olyckligt att det behövdes såpass mycket övertid för att slutföra projekten och tillade: "Vi försöker uppmuntra dem att arbeta normala arbetstider $i$ möjligaste mån

De långa arbetstiderna och det sätt på vilket samtalsdiskursen på "Microchips" formeras kring lagsport och lagspelsmetaforer är två exempel på hur en organisation institutionaliserar genusrelaterade arbetsformer. I det här fallet sammanfaller även den genusrelaterade arbetsformen med hur företaget utövar arbetsledning och hur de använder identitetsbaserade former för kontroll av de anställda. Den normativa kontrollen utövas här via en projektledning där arbetsformerna och språket för att beskriva dem hämtar erfarenheter från klassiskt manliga sfärer. Lagspelet förmodas referera till en manlig erfarenhetssfär och de långa arbetspassen heroiseras i termer av "manlig mystik» där ungkarlarnas arbetsrytm är den normgivande. Som anställd på ett företag som "Microchips» träder personen in i en organisation där specifika uppfattningar om vad som är manligt respektive kvinnligt är en del av arbetsformen. »Microchips« är ett företag som också är del av en bransch där en flexibel organisationsform är legio och där "fria» arbetstider är norm. De »fria» arbetstiderna innebär dock mestadels att man har friheten att arbeta så mycket man orkar. Marknadens logik är rådande där personer knappast förväntas ha några förpliktelser utanför arbetet. Åtminstone räknas andra förpliktelser inte in i tidsplaneringen av de olika projekten på företaget. Under den ungdomligt lediga ytan och informella stämningen på arbetsplatsen är det en tuff marknadslogik som styr arbetsrytm och social samvaro. Den pressade arbetsrytmen och hängivenhet inför arbetsuppgifterna är normer som ingenjörerna i hög grad internaliserat. Den här internaliseringen av arbetsvillkoren hänförs därför snarare till inre motivation och prestationsorientering än villkor uppsatta av arbetsledningen. Att inte kunna prestera på ett tillfredsställande sätt för den enskilde ingenjören blir därför någonting som ofta ses i termer av individuella brister och egenskaper. Arbetsdisciplinen i den här formen av normativ kontroll upprätthålls genom grupptryck och enskild prestationsångest istället för genom yttre inspektion och övervakning. Det har konsekvenser för livet utanför arbetet.

\section{"Vi är inte traditionella män»}

Samtidigt som ingenjörerna på företaget mer eller mindre internaliserat den formen av normativ kontroll så finns också förväntningar, drömmar och förhoppningar om ett "normaltı liv utanför arbetet. De manliga och kvinnliga ingenjörerna talade i intervjuerna om föräldraskap. Av de 15 ingenjörerna var fem män och en kvinna föräldrar till barn i förskoleåldern. För männen tog deras syn på föräldraskapet ofta avstamp i bilden av deras egna fäder. En återkommande åsikt var att de inte ville vara som 
deras egna fäder. De menade generellt att de såg alltför lite av sina egna fäder under uppväxten. Det fanns naturligtvis stora variationer men sammantaget var det en bild som framträdde. De såg sig generellt som »i-princip« män som självklart skulle vara jämställda i föräldraskapet. Barnens uppfostran var en gemensam angelägenhet för både mamman och pappan. Utifrån deras berättelser kan man kategorisera de flesta av deras egna pappor som "fritidspappor« till skillnad från deras egna ambitioner att vara "vardagspappor" (Åström 1990). Umgänget med deras egna fäder har ofta kommit att ske via en gemensam fascination inför teknik. Det är ett intresse som förenat far och son samt även far och dotter men för de manliga ingenjörerna har det setts som en självklar del i deras fostran.

Sönerna har tidigt tagit del i faderns sysselsättningar och föräldrarna har i hög grad uppmuntrat deras tekniska intresse genom att tillåta pojkarna att tidigt "meka» med allehanda former av teknik. Den här självklara attityden till teknik är någonting många av de manliga ingenjörerna delar. Deras nuvarande yrke beskrivs som en självklar fortsättning på ett tidigt umgänge och intresse för teknik. En av ingenjörerna på "Microchips» (Anton) uttrycker det på följande sätt:

Ja, jag har alltid varit intresserad av teknik och har alltid hällit på att pula med cyklar och mopeder och sånt där. Det har jag alltid gjort, jag har alltid varit fixaren helt enkelt. Sist jag var hemma höll jag och pappa på med diskmaskinen. Vi fick inte riktigt till det så vi höll på till fyra på natten. Då kom vi fram till att det var magnetventilen det var fel på. Först måste man ju skruva isär allting och titta hur det fungerar men det var den till slut, den som släpper in vattnet. Störd blev jag, för jag visste inte hur den fungerade, ja nyfikenheten måste stillas helt enkelt. Ja, jag har pulat med elektronik så länge jag kan minnas och det gör jag ju fortfarande. Det är nog typiskt både för pappa och mig.

I Antons livsberättelse så representerar teknik en tydlig social kontinuitet. Det upprätthåller en linje tillbaks till barn- och ungdomen och en typ av sysselsättning som han och hans far delar. Samtidigt är Anton tydlig med att han inte vill bli som sin far. De tillfällen han verkligen fick kontakt med sin far var när de delade praktiska göromål. Utöver det menar Anton att hans far var en relativt frånvarande figur trots att han nästan alltid var fysiskt närvarande på gården där Anton växt upp. Det är inte den formen av faderskap som Anton ser framför sig den dagen han bildar familj. Han vill vara en närvarande pappa som barnen kan dela alla sina bekymmer och glädjeämnen med. Han vill vara en aktiv fader i ett jämställt föräldraskap.

På det sätt han artikulerar sina tankar kring sin roll som man och framtida pappa vilket han hoppas kunna bli, tar han också avstånd från den typen av män som han ser i sin hemtrakt. Det är män som upprepar traditionella mönster av manligt och kvinnligt. Hans gamla kompisar som bor kvar i hembygden är "traditionella gubbar". De vill helst inte förändras och är nöjda med att »...kärringen går hemma". Han vill inte vara som dem. Att ta ut pappaledighet förutom möjligtvis två varma sommarmå- 
nader är enligt Anton otänkbart för dessa "gubbar". De ser sig själva som att de behövs utanför hemmets väggar eftersom livets praktikaliteter pockar på uppmärksamhet och "...de blir mest rastlösa av att bara vara med ungarna".

I hans livsberättelse såväl som en del av de andra manliga ingenjörernas finns det ett avståndstagande från den typen av pojkar och män som visat sin "grabbighet" genom tuffhet, styrka och "coola" attityder. Det avspeglar erfarenheter av att inte vara de tuffa och "coola» killarna och visar på en viss form av marginalisering under skoltiden. Det senare åtminstone i termer av att inte vara de populära i skolan. Som både ingenjörerna Conny och Anton påpekar så var det delvis deras datorintresse som gjorde att de blev marginaliserade och betraktades som "nördar" under framförallt högstadiet. De hävdade sig inte genom styrka eller atletisk förmåga, utan deras umgänge var tillsammans med andra pojkar och fokuserades kring datorer och nya PCspel. Det här var enligt Conny tiden innan en PC blev var mans egendom och spelmarknaden hade exploderat på det sätt den gjort senare. De delar här erfarenheter av de första hemdatorerna. Erfarenheter som de idag skrattar gott åt och som de nostalgiskt kan hänge sig åt i timmar. När de idag jämför sina egna liv med exempelvis "gubbarna" så talar de ibland skämtsamt om det som en form av "nördarnas revansch". Enligt många ingenjörer jag talat med efter undersökningen på „Microchips» har ju samhällsutvecklingen också gett dem rätt i och med att personer som exempelvis Bill Gates och Linus Torvaldsson (skaparen av Linux) fått en heroisk status inom samhälle och näringsliv. Deras framgång har också kommit att legitimera "nördarna».

I avståndstagandet från "fritidspappor" och "gubbarna" så utkristalliseras andra maskulina ideal. För de ingenjörer jag intervjuat är därför ett jämställdhetsideal ett av de värden som de ser centralt och självklart. Det finns uppenbarligen både ideologiska och personliga orsaker till det. I praktiken är det inte lika lätt att upprätthålla detta ideal.

\section{Den oundvikliga konflikten?}

Ingen av de intervjuade ingenjörerna på "Microchips" menar att det borde vara någon motsättning mellan arbete och familj men att det i realiteten nästan alltid är det och att det innebär ständiga kompromisser. I de kompromisserna är det sällan familjeliv- eller vänskapsrelationer som prioriteras. Arbetslivet är genomgående det som sätts i främsta rummet. De vet sällan hur många timmar de arbetat per vecka och struntar ofta i att försöka ta reda på det. Deras arbetsmotivation räknas inte i antalet arbetstimmar. Det är snarare att få vara med i utvecklingen av en spetsteknologi, att vara med i ett kreativt och spännande arbetslag och få vara del av en liten och informell arbetsplats till skillnad från de stora företagen inom IKT-sektorn. För ingenjörerna på »Microchips» blir det också mycket påtagligt då Nokia och Ericsson finns inom nära räckhåll i den teknik- och forskningspark där företaget har sina lokaler. De stora jättarna på andra sidan vägen omtalas oftast i termer av den "grå massan" och »byråkratfabrikerna». Ingenjörerna på 
"Microchips» känner sig privilegierade att få vara en del av ett företag i frontlinjen. Om utvecklingen av den halvledarteknologi som de arbetar med slår igenom på marknaden finns naturligtvis drömmen och chansen att de kan bli förmögna om företaget blir uppköpt av något större företag.

Samtidigt är det uppenbart att den "aura» av spetsteknologi som ingenjörerna känner att de är en del av också är en orsak till de långa "obetalda" övertidstimmarna. Den tuffa marknadslogiken som styr företagets villkor omtalas i en jargong som får det att framstå som en väsentligt annorlunda uppgift att arbeta på "Microchips« i jämförelse med exempelvis Ericsson. Det är samtidigt en marknadens maskulinitet där framförallt ungkarlarnas arbetsrytm och långa arbetspass framstår som det önskvärda för den normativa kontroll som företaget mer eller mindre omedvetet arbetar med.

Med den här formen av arbetsmarknadsvillkor är den omsorgsrationalitet som tillhör livet utanför arbetet satt på undantag. Det är tydligt för småbarnsföräldrarna på företaget. Kalle och Michael är två av de ingenjörer som var småbarnsföräldrar och hade arbetat på företaget $i$ tre år vid tiden för min undersökning. För dem båda hade föräldraskapet tydliggjort de "fria» arbetstidernas gissel. Trots den till synes generösa och flexibla arbetsordningen hade de båda ständigt dåligt samvete för att de inte arbetade lika mycket som sina kollegor eftersom de hade förpliktiganden som inte gick ihop med leveranstider till kund. Vid slutfasen av min undersökning funderade de bägge på att byta jobb vilket de cirka ett halvår senare gjorde. Deras motiv var att det inte gick att kombinera familjeliv och arbete samt att deras respektive partners krävde utrymme för sina arbeten och karriärer.

För de fyra andra småbarnsföräldrarna beskrevs livet som ett ständigt pusslande. Den kvinnliga ingenjören Ingrid funderade ständigt på hur hon skall kunna planera sin arbetstid så att hon hann med vad hon föresatt sig att göra samtidigt som hon skall hinna hämta sin dotter på dagis på eftermiddagen. Hon satte i system att börja vid 6-tiden på morgonen de dagar när hennes man kunde lämna dottern på dagis. I övrigt använde hon helger ibland även om hon i möjligaste mån försökte undvika det. Hon hade ett ständigt dåligt samvete för att hon inte gjorde tillräckligt på arbetet och i hemmet. Hon upplevde vidare att hon missade en massa information när hon inte längre kunde delta i det sociala livet som pågick utanför "normal arbetstid". De andra tre manliga ingenjörerna hade partners som tog hand om hemmet och de "hjälpte till» hemma. Sven menade att han gärna hade velat ta pappaledigt men att han dels upplevde att han inte hade tid eftersom han skulle förlora värdefulla kunskaper på jobbet och dels för att det var ekonomiskt ofördelaktigt då inkomstbortfallet skulle bli alltför stort. Dessutom wville Lena vara hemma. Hon tog det som ett skönt avbrott från jobbet som hon tröttnat påu. Liknande argument hörde jag även från de två andra manliga ingenjörerna samt från fem manliga ingenjörer vid Volvo PV som jag intervjuade kring samma frågeställningar. Det var en kombination av ekonomiska argument, vald ansvarsfördelning i hemmet och viljan att inte bli »avhängd" på arbetsplatsen.

Småbarnsföräldrarna återkom till den känsliga relationen mellan hem och arbete 
åtskilliga gånger i intervjuerna. Särskild uppmärksamhet ägnades olika vardagliga strategier för att hantera tidskonflikter och de olika sfärernas motstridiga krav samt inte minst de inre krav som de intervjuade ingenjörerna ställde på sig själva. Att arbeta i tvåskift var kanske den vanligaste strategin, $\mathrm{d}$ v s att förutom den vanliga arbetstiden använda kvällar och helger till att hinna med. Michael berättade exempelvis att:

Jag brukar som oftast känna mig stressad om jag inte gjort undan under kvällen. Det blir nästan oundvikligt så att jag sitter och jobbar en timme eller två varje kväll fast jag vet att Åsa (sambon) ogillar det. Visst, det blir en slitning oss emellan och egentligen handlar det väl om en slitning mellan jobbet och familjen. Man vill ju både och.

Strategin att arbeta tvåskift ackompanjerades dock ofta av en känsla att vara otillräcklig i båda sfärerna. Att vara både och upplevdes att inte vara tillräckligt mycket på något ställe. Livet med barn och sambo/ $\mathrm{fru} / \mathrm{man} /$ partner upplevdes genomgående som ett outsläckligt behov som inte kunde fyllas och arbetet som en ständig att göralista som aldrig tar slut som Sven uttryckte det. De manliga småbarnsföräldrarna reflekterade intressant nog ofta i termer av dubbla lojaliteter på ett sätt som man skulle kunna kalla traditionellt kvinnligt (ElwinNovak 2001). En dokumenterad känsla av otillräcklighet i relation till hem och arbetsliv präglade med andra ord intervjuerna med de manliga ingenjörerna.

Det är intervjusvar och argument som överensstämmer med den bild som tidigare forskning visat på (SOU 1998, Plantin 2001,
Klinth 2002). På ett liknande sätt överensstämmer ingenjörernas resonemang med de resultat som tidigare visat på en omorientering i mäns föräldraskap mot ett mer ansvarstagande och självklart föräldraskap där utgångspunkten är ett aktivt och jämställt ansvar för barn och hem (Hagström 1999). Samtidigt indikerar intervjusvaren även en förändring mot en genusordning där män är reflekterande kring sin egen otillräcklighet och oförmåga. En genusordning där en högre grad av emotionalisering och intimisering av mannen och det manliga präglar både hem och arbetsliv.

Icke desto mindre kvarstår stora klyftor mellan praktik och intentioner när det gäller ingenjörerna i den här undersökningen såväl som den större bild som tidigare forskning visat på, d v s huvudansvaret för hem och barn ligger hos kvinnor trots ett stort inträde av kvinnor på arbetsmarknaden sedan 1970talet. Den svenska arbetsmarknaden är uppdelad i manliga och kvinnliga yrkesområden och kvinnor återfinns inom offentlig sektor och män dominerar inom privat sektor (Hirdman 1998). Inom IKT-sektorn tydliggörs också den marknadens maskulinitet som står i kontrast till »i-princip« mannens intentioner kring ett aktivt och delat föräldraskap.

\section{Avslutning}

I den här artikeln har jag diskuterat relationen mellan två olika former av rationalitet och vilka är centrala för faderskapets utformande och nya maskulinitetsordningar; marknadens maskulinitet och en samtida stark jämställdhetsdiskurs.

Uppdelningen mellan hem och arbete är 
central för de ingenjörer som intervjuats. De känner att de »sitter i kläm» mellan krav hemma och på arbetet. En återkommande känsla de beskriver är att de inte räcker till. De fascineras av och är engagerade $i$ sitt arbete samtidigt som de uttrycker en önskan om ett aktivt och delat föräldraskap som är svårt att uppfylla. Kraven från arbetet är krav som de i hög grad ställer på sig själva. Även om olika "deadlines» och leveranstider till kund är krav som måste uppfyllas uttrycker de att det känns som personliga misslyckanden att inte klara av "deadlines». De lägger ofta skulden på sig själva och ifrågasätter sin egen kompetens även om de är medvetna om de orimliga prestationskraven som ställs på dem. Samtidigt formuleras arbetets krav i termer av att klara av och stålsätta sig. I arbetets praktik utformas kraven i relation till vad som förknippas med manlighet. Arbetsledningen är ambivalent till de långa arbetstiderna eftersom rådande prestationskrav är en del av de pressade ekonomiska förutsättningarna med krav på avkastning och vinstmarginaler. I praktiken understödjer de dock den här formen av normativ kontroll.

Samtidigt uttrycker de här männen att de vill dela föräldraskapet. De ger på flera olika sätt uttryck för en rådande stark jämställdhetsdiskurs i det svenska samhället och verkar till synes dela den. De distanserar sig gentemot deras fäder som de upplevt som alltför frånvarande under deras egna uppväxter. De distanserar sig från män som ger uttryck för traditionella könsmönster. De vill vara "moderna" fäder, $\mathrm{d}$ v s närvarande och betydelsefulla för sina barn. På så sätt uttrycker de erfarenheter och argu- ment för en ny och framväxande maskulinitetsordning. Med andra ord en ökande grad av emotionalisering och intimisering av maskulinitet och manlig genusordning (Backman 2005). De är del av en ny form av manlig sensitivitet som uttrycks på diskursiv nivå såväl som i vardagliga erfarenheter. Intentioner och praktik överensstämmer dock inte. Prioritetsordningen för de här männen är arbete och sedan familjeliv. Den normativa och genusbaserade form av kontroll som råder på arbetsplatsen är överordnad hemmets krav.

Kontroll och disciplinering formuleras här i termer av inre kontroll. De intervjuade ingenjörerna administrerar sin egen självkontroll samtidigt som de i sina vardagsliv lever med att produktionens krav är överordnad reproduktionens. Trots en generell omorientering mot ett mer jämställt föräldraskap och nya former för manlig sensivitet som även dessa män delar har de svårt att praktisera ett aktivt och jämställt föräldraskap p g a en arbetsordning där marknadens maskulinitet är prioriterad framför faderskapet. Det är ett tydligt dilemma för de män som intervjuats i denna undersökning samt ett generellt problem för män som lever med olika maskulinitetsordningar hemma och på arbetet (Plantin 2001, Klinth 2002).

De genusteoretiska implikationerna av denna dubbla lojalitet och nya framväxande maskulinitetsordningar bör då följaktligen vara att försöka överbrygga den analytiska uppdelningen mellan hem och arbete. Att arbetets genusordning är nära sammankopplad med hemmets genusordning är tydligt och väldokumenterat (Stark 1997, Björnberg \& Kollind 2003). I ambitionen 
att analytiskt försöka överbrygga hemmets respektive arbetets genusordning är det viktigt att se hemlivets organisering i ljuset av arbetets symboliska ordning. I förståelsen av samtida genusordning är det centralt att exempelvis försöka se hur nya maskulinitetsordningar formas i nya arbetsvillkor och produktionens omvandling.

Trots en stark jämställdhetsdiskurs som delas av många män idag är relationen mellan produktionens och reproduktio- nens rationalitet stadigvarande ojämlik. Arbetsmarknadens hierarkisering och symboliska ordning skapar också asymmetri i det moderna faderskapets praktik. För att kunna fånga genusordningens vardagsliv och meningsskapande processer när det gäller hem och arbete behöver vi fokusera mäns respektive kvinnors rörelse mellan familj och produktion och hur genusidentitet förhandlas mellan dessa olika sfärer.

\section{Referenser:}

Adkins, Lisa (2002) Revisions: gender \& sexuality in late modernity. Philadelphia: Open University Press.

Alvesson, Mats \& Due-Billing, Yvonne (1997) Understanding Gender and Organizations. London: Sage Publications.

Alvesson, Mats (1998) „Gender relations and identity at work: A Case Study of Masculinities and Femininites in an Advertising Agency». Human Relations 51:8s. 969-1006.

Asplund, Gisele (1984) Karriärens villkor: Män, kvinnor och ledarskap. Stockholm: Prisma.

Backman, Stina (2005) Den sjuke mannen. Populärkulturella gestaltningar av manlig ohälsa. Stockholm: Carlssons.

Berg, Lars-Erik \& Johansson, Thomas (1999) Den andre föräldern: Om deltidspappor och deras barn. Stockholm: Carlssons.

Bergkvist, Christina \& Florin, Christina (red.) (2004) Framtiden $i$ samtiden. Könsrelationer $i$ förändring i Sverige och omvärlden. Stockholm: Institutet för framtidsstudier.

Björnberg, Ulla \& Kollind, Anna-Karin (2003) Att leva själv tillsammans. Malmö: Liber.

Brewer, John D (1994) "The Ethnographic Critique of Ethnography: Secterianism in the RUC", Sociology, Vol 28, no 1, s. 35-56.
Cooper, Marianne (2000) "Being the "Go-to-guy»: Fatherhood, Masculinity, and the Organization of Work in Silicion Valley", Qualitative Sociology, Vol. 23, No 4, s. 379-405.

Duvander, Ann-Zofie (2000) Couples in Sweden: Studies on Family and Work. Stockholm: Swedish Institute for Social Research.

Elwin-Novak, Ylva (2001) I sällskap med skulden: om den moderna mammans vardag. Stockholm: Bonnier.

Etzioni, Amitai (1961) A comparative analysis of complex organizations: on power, involvement, and their correlates. New York: Free Press.

Fogelberg-Eriksson, Anna (2005) Ledarskap och kön. En studie av ledare och maskuliniteter $i$ ett verkstadsföretag. Linköping: Linköping Studies in Education and Psychology No. 102.

Gavanas, Anna (2001) Masculinizing Fatherhood: Sexuality, Marriage and Race in the U.S. Fatherhood Responsibility Movement, Department of Social Anthropology, Stockholm University.

Gunnarsson, Ewa (2003) »I skuggan av dominerade diskurser. Konstruktioner av kön bland nomader och jordade i flexibla organisationslandskap». I Johansson, Thomas \& Kousmanen, Jari (red.) Manlighetens många ansikten. Fäder, feminis- 
ter, frisörer och andra män. Malmö: Liber.

Hagström, Charlotte (1999) Man blir pappa. Föräldraskap och maskulinitet i förändring. Lund: Nordic Academic Press.

Hirdman, Yvonne (1998) "State policy and gender contracts: the Swedish experience». I Eileen Drew, Ruth Emerek \& Evelyn Mahon (eds.) Women, Work and the Family in Europe. London: Routledge.

Holgersson, Charlotte (2003) Rekrytering av företagsledare. En studie i homosocialitet. Stockholm: EFI.

Hondagneu-Sotelo, Pirette \& Messner, Michael A. (1994) "Gender Displays and Men's Power. The 'New Man' and the Mexican Immigrant Man«. I Brod, Harry \& Michael Kaufman (eds.), Theorising Masculinities. London: Sage.

Jalmert, Lars (1984) Den svenske mannen. Stockholm: Tiden.

Johansson, Thomas (2001) „Fadern som försvann. Diskursiva och sociala spåru. I Claes Ekenstam, Thomas Johansson \& Jari Kousmanen, (red.) Sprickor i fasaden: Manligheter $i$ förändring. Hedemora: Gidlunds.

Kimmel, Michael (1994) „Masculinity as Homophobia: Fear, Shame, and Silence in the Construction of Gender Identity». I Brod, Harry \& Kaufman, Michael (eds.) Theorizing Masculinities. London: Sage.

Klinth, Roger (2002) Göra pappa med barn. Umeå: Borea.

Kunda, Gideon (1992) Engineering culture: control and commitment in a high-tech corporation. Philadelphia: Temple Univ. Press.

Mellström, Ulf (1995) Engineering Lives, Techno logy, Time and Space in a Male-Centred World, Linköping Studies in Art and Science, nr 128, Linköping Univ.
Mellström, Ulf (1999) Män och deras maskiner. Nora: Nya Doxa.

Mellström, Ulf (2002) „Patriarchal machines and masculine embodiment", Science, Technology \& Human Values, Vol. 27 No. 4, autumn 2002, s. 460-478.

Mellström, Ulf (2003) Masculinity, Power and Technology: A Malaysian Ethnography. Ashgate: Oxon U.K.

Mellström, Ulf (2004) «Machines and masculine subjectivity, technology as an integral part of men's life experiences", Men and Masculinities, volume 6, Number 4, April 2004, s. 368-383.

Nordberg, Marie (2005) Jämställdhetens spjutspets? Manliga arbetstagare $i$ kvinnoyrken, jämställdhet, maskulinitet, femininitet och heteronormativitet, Göteborg: Bokförlaget Arkipelag.

Oláh, Livia Sz (2001) Gendering Family Dynamics: The Case of Sweden and Hungary, Stockholm: Stockholms universitet.

Pfeil, Fred (1995) White Guys. Studies in Postmodern Domination and Difference. London: Verso.

Plantin, Lars (2001) Män, familjeliv och föräldra skap. Umeå: Boréa.

Stark, Agneta (red.)(1997) Ljusnande framtid eller ett långt farväl?: den svenska välfärdsstaen $i$ jämförande belysning: rapport till Utredningen om fördelningen av ekonomisk makt och ekonomiska resurser mellan män och kvinnor. SOU ISSN 0375-250X. Stockholm: Fritzes.

SOU 1998:003 Välfärdens genusansikte. Rapport till kvinnomaktutredningen. Stockholm: Fritzes.

Åström, Lissie (1990) Fäder och söner. Bland svenska män i tre generationer. Stockholm: Carlssons. 


\section{Summary}

\section{New Fathering? Men and Fathers in the New Economy}

This article suggests that new configurations of masculinity are constructed in accordance with new processes of labour control and family life. It draws upon participant observation and interviews with engineers, men and fathers in a small semiconductor company. These men articulate a position in-between a strong discourse of gender equality and a working life based upon identity-based forms of control. This normative form of control is exercised through long working hours, dedication and commitment to projects performed in an environment where innovation and creativity are the key-words. This goes hand in hand with what Kimmel (1994) labels a market-place manhood. This form of masculinity is also congruent with the strong symbolic connection between men and machines as well as men and sport. In daily work at the company this is expressed through metaphors, story telling and generally an informal flow of meaning derived from predominantly manly styles of interaction. It reflects a socialising continuity in the world of males based in the sphere of production.
However, these men also express attitudes of a modern masculinity, ideologically, if not always practically, being committed to fatherhood and an equal division of labour between themselves and their partners. In this, they also distance themselves from traditional forms of masculinity. They believe in a fair domestic distribution of household tasks and parenthood, but also experience a major dilemma in being squeezed in-between the demands of production and reproduction. This dilemma is something they constantly negotiate in their movements between work and home. Their gendered subjectivity is shaped in this connection between gender, work and family. The conclusions of this article call for highlighting the centrality of gender in the organisation of work and the ways in which it affects family practices. It also calls for studying gendered subjectivity, work and family issues in a holistic manner, bridging the divisions between these different spheres of practice. 